\title{
Toimintatavan opas ketun lopetukseen
}

\author{
Hannu T. Korhonen \& Hanna Huuki \\ MTT, Kotieläintieteen laitos, 69100 Kannus, hannu.t.korhonen (at)mtt.fi
}

\section{Tiivistelmä}

Hyvän toimintatavan oppaan (HTO) tarkoituksena on tarjota työkalut kettujen hyvinvoinnin takaamiseksi lopetuksen aikana. Oppaassa käsitellään keskeisiä muuttujia, onnistuneen lopetustapahtuman tunnusmerkkejä ja toimintaohjeiston laatimista. Lopetuksen suorittavilla henkilöillä on oltava kelpoisuustodistus tai henkilöt on opastettu lopetusmenetelmien käyttöön ja työtä valvoo henkilö jolla on voimassa oleva kelpoisuustodistus. Ennen lopetusta toimijan on laadittava toimintasuunnitelma, jossa ohjeistetaan lopetuksen menetelmä, sekä määritellään vähintään Neuvoston asetuksessa (EY) N:o 1099/2009 säädetyt valvottavat muuttujat. Lopetuksen aloittamisesta on ilmoitettava toimivaltaiselle viranomaiselle. Lisäksi on määriteltävä toimenpiteet, jos laitteisto on epäkunnossa tai eläimet eivät tainnu ja kuole odotetusti. HTO:ssa käydään läpi asetuksen säädökset kelpoisuustodistuksesta ja sen vaatimuksista, sekä ohjeistetaan ja annetaan esimerkkejä lopetusasetuksen mukaisen toimintasuunnitelman laatimiseen.

Asetus sallii lopetuksen useilla menetelmillä; päähän ja kehoon kohdistetulla sähköiskulla, lopetus puhtaalla hiilimonoksidilla (> $4 \% \mathrm{CO}$ ), hiilimonoksidilla muiden kaasujen kanssa (>1 \% CO) ja ampumalla. Lisäksi asetus sallii kettujen tainnuttamisen päähän kohdistuvalla sähköiskulla tai lävistävällä pulttipistoolilla, joiden jälkeen lopetus on välittömästi varmistettava jotain muuta lopetusmenetelmää käyttäen. Päähän kohdistuva isku on sallittu vain hätälopetusmenetelmänä. Muita menetelmiä kuin sähkölopetusta käytetään ketun lopetuksessa hyvin harvoin, ja päähän ja kehoon kohdistetun sähköiskun on todettu olevan tehokas lopetusmenetelmä, joka aikaansaa nopean tajunnan menetyksen ja kuoleman.

HTO:ssa käsitellään myös niitä ominaisuuksia, mitä hyvällä lopetuslaitteella tulisi olla. Lopetukseen käytettävien laitteiden valmistajat ovat velvollisia antamaan ohjeet $\mathrm{mm}$. laitteen käyttötavasta, sille tarkoitetuista eläinmääristä ja laitteen huollosta. Tämän vuoksi kaupallisten laitteistojen käyttäminen lopetuksessa on suositeltavaa. Laitteen valmistajan ohjeet on otettava huomioon toimintaohjeistoa laatiessa ja laitteistoja huollettaessa. Lopetuksen aikana on seurattava lopetuksen kannalta keskeisiä muuttujia, joita sähkölopetuksessa ovat vähimmäisvirta $(0,3 \mathrm{~A})$, vähimmäisjännite $(110 \mathrm{~V})$, enimmäistaajuus $(\mathrm{Hz})$, vähimmäisaltistusaika (> $3 \mathrm{~s})$, enimmäisaika tainnutuksesta lopetukseen, välineiden kalibrointitiheys, sähkövirran optimointi, sähköiskujen estäminen enne tainnutusta ja elektrodien paikka ja kosketuspinta-ala. HTO:ssa käydään läpi, miten eri muuttujat vaikuttavat lopetuksen onnistumiseen. Ennen nahkomisen aloittamista on varmistettava, että jokainen eläin on kuollut. Oppaassa käydään läpi menetelmiä tajuttomuuden ja kuoleman varmistamiseksi.

Asiasanat: Turkiseläintuotanto, hyvinvointi

\section{Johdanto}

Hyvän toimintatavan oppaan tarkoituksena on tarjota työkalut tarhattujen hopeakettujen (Vulpes vulpes) ja sinikettujen (Vulpes lagopus) ja näiden lajiristeymien hyvinvoinnin takaamiseksi lopetuksen aikana. Oppaassa tullaan käsittelemään menetelmäkohtaisesti keskeisiä muuttujia, onnistuneen lopetustapahtuman tunnusmerkkejä ja toimintaohjeiston laatimista. Hyvän 
toimintatavan opas perustuu uusimpiin tieteellisiin tutkimustuloksiin (Korhonen \& Huuki, 2012, 2013a,b; Korhonen et al. 2012, 2013) ja se soveltuu tuottajien apuvälineeksi lopetuksen suunnitteluun ja lopetuksen raportointiin

Kettujen lopettamiseen on olemassa monia hyväksyttäviä menetelmiä. Muita menetelmiä kuin sähkölopetusta käytetään kuitenkin harvoin. Tämä hyvän toimintatavan opas antaa käytännön ohjeita ja esimerkkejä kettujen kaikista Euroopan neuvoston asetuksessa (EY) N:o 1099/2009sa kettujen lopetuksessa sallituista lopetus- ja tainnutusmenetelmistä. Muita menetelmiä, kuin sähkölopetusta käytetään kettujen lopetuksessa harvoin, eikä näiden menetelmien toimivuutta ole tutkittu eläimen hyvinvoinnin näkökulmasta. Sähkölopetusta tulisi pitää ensisijaisena lopetusmenetelmänä ketulla.

\section{Hyvän kuoleman määritelmä}

Termi eutanasia on peräisin kreikankielisistä termeistä "hyvä" (eu) ja "kuolema" (thanatos). Eläimen "hyvä kuolema" on sellainen, jossa eläin kokee mahdollisimman vähän kipua, tuskaa ja kärsimystä.

Lopetuksella tarkoitetaan tarkoituksella tehtyä toimenpidettä, jonka seurauksena eläin kuolee. Voimassaolevien asetusten yhteydessä voidaan lopetuksen kuitenkin käsittää tarkoittavan hyvän kuoleman tuottamista eläimelle, sillä Euroopan neuvoston asetuksen (EY) N:o 1099/2009 tarkoituksena on vähentää kipua, tuskaa ja kärsimystä lopetuksen ja siihen liittyvien toimenpiteiden aikana.

Hätälopetus tarkoittaa sellaisten eläimien lopetusta, jotka ovat vahingoittuneet tai joilla on sairaus, josta seuraa vakavaa kipua tai kärsimystä, jota ei voida muilla toimenpiteillä lievittää.

\section{Lopetusmenetelmät}

Euroopan neuvoston asetus sallii kettujen lopettamisen päähän ja kehoon kohdistuvalla sähköiskulla sekä päähän kohdistuvalla sähkötainnutuksella, kun sitä seuraa välittömästi kuoleman varmistava toimenpide. Sähkölopetuksen lisäksi kettuja saa lopettaa puhtaalla hiilimonoksidilla tai hiilimonoksidilla yhdessä muiden kaasujen kanssa (esim. pakokaasun hiilimonoksidi). Tilapäisesti ja hätätoimenpiteenä kettuja saa lopettaa lävistävällä pulttipistoolilla tai ampumalla. Jos kettu painaa alle $5 \mathrm{~kg}$, se voidaan myös lopettaa iskulla päähän. Tätä menetelmää ei kuitenkaan saa käyttää pääasiallisena lopetusmenetelmänä, eikä yksi henkilö saa lopettaa enempää kuin 70 eläintä vuorokaudessa. Kaikista näistä menetelmistä päähän ja kehoon kohdistuva sähkölopetus on yleisimmin käytetty. Päähän ja kehoon kohdistuvaa sähkölopetusta suositellaan käytettäväksi ensisijaisena lopetusmenetelmänä, sillä sen on todistettu oikein suoritettuna aiheuttavan välittömän tajunnan menetyksen ja nopean kuoleman.

\section{Lopetuksen tehokkuuden valvonta}

Toimijan on suunniteltava lopetustoimenpiteet etukäteen laatimalla toimintaohjeisto. Hänen on varmistettava, että lopettaminen suoritetaan toimintaohjeiston mukaisesti. Lopetuksen tehokkuutta on valvottava seuraamalla erilaisia muuttujia, jotka ovat keskeisiä lopetuksen onnistumiseen vaikuttavia tekijöitä.

Parhaista mahdollisista teknisistä ja fyysisistä olosuhteista huolimatta lopetustilanne voi aiheuttaa eläimelle kipua, tuskaa, pelkoa ja muita kärsimyksen muotoja. Kaikkien lopetukseen 
osallistuvien henkilöiden tulee tehdä kaikki tarvittavat toimenpiteet kivun lievittämiseksi ja kärsimyksen minimoimiseksi lopetuksen aikana.

Lopetuksen tehokkuuden seuranta perustuu tyypillisesti eläimen tietoisuuden tason ja tuntemiskyvyn arvioimiseen.

Tietoisuutta voidaan pitää eläimen kykynä tuntea tunteita ja kontrolloida tahdonalaisia toimintojaan. Eläimen voidaan useimmiten katsoa olevan tajuton, kun se kadottaa luonnollisen seisoma-asennon, ei ole hereillään eikä osoita merkkejä positiivisista tai negatiivisista tunnetiloista, kuten pelosta tai kiihtymyksestä.

Tuntemiskykynä voidaan pitää eläimen kykyä kivun tuntemukseen. Eläimen voidaan olettaa olevan tuntemiskyvytön, kun se ei reagoi äänen, hajun, valon tai fysikaalisen kotaktin aiheuttamiin ärsykkeisiin.

Päähän ja kehoon kohdistuva sähkötainnutus aiheuttaa aivoissa oikein annettuna epileptisen tilan, joka aiheuttaa toonisen (lihasjännitystä ylläpitävä) kouristuksen ja kloonisia (tahdottomasti nykivä) kouristuksia, tajuttomuuden ja lopulta aivokuoleman (5 minuutin kuluessa). Sähköisku vaikuttaa sydämeen aiheuttamalla välittömästi kammiovärinän ja sydämen pysähtymisen viimeistään muutaman minuutin kuluttua. Sydän ei voi kammiovärinän vuoksi pumpata riittävästi verta aivoihin, josta seuraa hapen puutos aivoissa ja lopulta aivokuolema. Eläin on tajuton koko toimenpiteen ajan. Onnistuneessa lopetuksessa hengitys lakkaa välittömästi sähkötainnutuksen jälkeen.

Varmistaakseen, että olosuhteet lopetuksen onnistumiseksi ovat oikeat, on toimijan määritettävä mitattavat muuttujat, jotka on esitetty Neuvoston asetuksessa (EC) No 1099/2009. Hänen on suoritettava säännöllisiä tarkistuksia varmistuakseen, että lopetus etenee määriteltyjen olosuhteiden mukaisesti. Tarkastustiheys riippuu lopetuksen tehokkuuteen vaikuttavista tekijöistä ja aiempien tarkastusten tuloksista. Ennen nahkomisen aloittamista on varmistettava, että eläin on kuollut. Yksilöllinen tarkistus voidaan tehdä kokeilemalla lihasjännitystä, silmän sarveiskalvorefleksiä ja tarkistamalla, että sydän on pysähtynyt ja hengitys lakannut (ks. kappale 8.2). Tuottajan on pidettävä kirjaa lopetuksen onnistumisen seurannasta.

\section{Mitattavat muuttujat}

Jokaista lopetusmenetelmää koskevat mitattavat muuttujat on kirjattu Neuvoston asetuksessa. Nämä mitattavat muuttujat ovat tekijöitä, joilla on keskeinen vaikutus lopetuksen onnistumiseen. Seuraavissa kappaleissa esitellään nämä muuttujat ketuille sallittujen lopetusmenetelmien osalta.

\section{Sähkölopetus}

Neuvoston asetuksen mukaan toimijan on määriteltävä keskeiset lopetuksen onnistumiseen vaikuttavat muuttujat ja suoritettava niille säännöllisiä tarkastuksia lopetuksen aikana. Tarkastus tiheys riippuu aiempien tarkastusten tuloksista ja kaikista niistä tekijöistä, jotka vaikuttavat lopetuksen tehokkuuteen. Taulukossa 1 on esitetty ketun sähkölopetuksessa mitattavat muuttujat.

\section{Vähimmäisvirta, vähimmäisjännite ja enimmäistaajuus}

Jos jännite pidetään vakiona, saatu virtamäärä (A) riippuu kudoksen vastuksesta eli impedanssista. Vastus kasvaa eläimen koon kasvaessa ja karvapeitteen lisääntyessä. Vastusta vähentäviä tekijöitä ovat kasvava jännite, elektrodien kontaktipinta-ala, ihon kosteus ja 
elektrodien pitämisessä käytetty kosketuspaine. Sähköiskua annettaessa on pidettävä huoli, että jännite on riittävän suuri läpäistäkseen kudosvastuksen. Päähän ja kehoon kohdistuvassa sähkölopetuksessa sähkövirta aiheuttaa sydämen kammiovärinän, sydänpysähdyksen ja epileptisen kohtauksen aivoissa. Kun käytetään vaihtovirtaa (AC) sydämeen kohdistuva vaikutus riippuu virran taajuudesta $(\mathrm{Hz})$; matalampitaajuuksinen virta on parempaa kuin korkeataajuuksinen.

Jos virta on liian heikko aiheuttaakseen epileptisen kohtauksen aivoissa, tai virta ei jostain syystä kulje aivojen läpi, eläin saattaa pysyä tajuissaan sähkölopetuksen aikana. Tällaisessa tapauksessa eläin on tajuissaan, vaikka se ei kykene liikkumaan sähkön antamisen aikana, ja se saattaa olla liikuntakyvytön vielä jonkin aikaa sähköiskun jälkeen. Ihmisillä sydämen pysähdystä on kuvattu hyvin kivuliaaksi ja sähkön aiheuttamat lihaskouristukset voivat olla riittävän voimakkaita aiheuttamaan murtumia selkärangassa.

Taulukko 1. Keskeiset seurattavat muuttujat kettujen päähän ja kehoon kohdistuvassa sähkölopetuksessa

Muuttuja

Päähän ja kehoon kohdistuva sähkölopetus

\begin{tabular}{|c|c|}
\hline Vähimmäisvirta (A tai mA) & - $\quad 0.3 \mathrm{~A}$ \\
\hline Vähimmäisjännite (V) & - $110 \mathrm{~V}$ \\
\hline Enimmäistaajuus (Hz) & - $100 \mathrm{~Hz}$ (suositus) \\
\hline Vähimmäisaltistusaika(s) & - $\quad \geq 3 \mathrm{~s}$ (suositus $\geq 5 \mathrm{~s})$ \\
\hline Välineiden kalibrointitiheys & $\begin{array}{l}\text { - } \text { Vähintään kerran vuodessa } \\
\text { - Akun lataus niin usein kuin on tarpeen - } \\
\text { lopetuksen aikana vähintään päivittäin } \\
\text { - Mittari ja näyttö helpottavat laitteiston } \\
\text { toimintakunnon seuraamista }\end{array}$ \\
\hline Virran optimointi & $\begin{array}{l}\text { - } \quad \text { Elektrodien oikeat kohdat ja kosketuspaine } \\
\text { - Riittävä jännite ja virta suhteessa eläimen } \\
\text { kokoon } \\
\text { - Fyysinen ympäristö ja sähkön väärän } \\
\text { johtumisen estäminen }\end{array}$ \\
\hline $\begin{array}{l}\text { Sähköiskujen estäminen ennen } \\
\text { tainnutusta }\end{array}$ & $\begin{array}{ll}\text { - } & \text { Virtakytkin } \\
\text { - } & \text { Suoja sateelta ja kosteudelta } \\
\text { - } & \text { Johtamattomien materiaalien käyttö } \\
& \text { liikkumisen estoon käytettävissä laiteissa } \\
\text { - } & \text { Ympäristön puhtaus } \\
\end{array}$ \\
\hline $\begin{array}{l}\text { Elektrodien paikka ja } \\
\text { kosketuspinta-ala }\end{array}$ & $\begin{array}{l}\text { - Yksi elektrodi asetetaan ketun peräsuoleen } \\
\text { ja toinen suuhun. Pitkulaiset elektrodin } \\
\text { johtavat virran tarkasti }\end{array}$ \\
\hline $\begin{array}{l}\text { Enimmäisaika tainnutuksesta } \\
\text { lopetukseen pelkän } \\
\text { tainnuttamisen yhteydessä }\end{array}$ & $\begin{array}{l}\text { - Jos päähän ja kehoon kohdistettu } \\
\text { sähkölopetus suoritetaan oikein, kuolema } \\
\text { tapahtuu minuuttien kuluttua. } \\
\text { • Jos käytetään kaksivaiheista } \\
\text { sähkötainnutusta, lopettava sähköisku on } \\
\text { annettava viipymättä }\end{array}$ \\
\hline
\end{tabular}




\section{Vähimmäisaltistusaika}

Kettu tulisi altistaa sähkövirralle vähintään kolmen sekunnin ajan. On todistettu, että kettu saattaa tulla tajuihinsa uudelleen kammiovärinän ja kouristusten jälkeen, jos altistusaika on vähemmän kuin kolme sekuntia. Laitteen valmistajan suosituksia laitteen käyttötavasta ja altistusajasta tulee noudattaa, erityisesti siinä tilanteessa, jos laitteen valmistaja ilmoittaa suositeltavan altistusajan pidemmäksi kuin kolme sekuntia. Isokokoiset ketut saattaa olla tarpeen altistaa sähkövirralle kauemmin kuin 3 sekuntia, sillä ketun iso koko lisää kehon vastusta.

\section{Laitteen kalibrointitiheys}

Laitteen valmistajien velvollisuus on ilmoittaa lopetuslaitteen tekniset tiedot ja antaa ohjeet laitteen oikeasta käytöstä ja huollosta. Turkiselinkeinon toimijan tehtävänä on varmistaa, että laitetta ylläpitävät ja huoltavat siihen pätevöityneet henkilöt. Ennen lopetuksen aloittamista on varmistettava, että laite tuottaa riittävän korkean virran ja jännitteen, jonka taajuus on riittävän matala. Myös akun toimintakunto on tarkistettava. Akku on ladattava tai vaihdettava riittävän usein lopetettavien eläinten määrästä riippuen. Laitteistoon liitettävä mittari ja näyttö helpottavat toimijaa seuraamaan laitteiston toimintakuntoa, sillä varauksen väheneminen ja laitteiston toimintahäiriö on helposti nähtävissä jännitteen ja virran muutoksina.

Mikäli sähkölopetuslaite menee epäkuntoon, sen saa korjata vain sellainen henkilö, jolla on tarvittava pätevyys ja lupa laitteen korjaamiseen. Huolto- ja korjaustoimenpiteet tulee suorittaa valmistajan ohjeiden mukaisesti. Kunnossapidosta on myös pidettävä kirjaa. Kirjanpito on säilytettävä vähintään vuoden ajan.

\section{Sähkövirran optimointi}

Elektrodien paikka ja muoto, sekä voima, jolla elektrodeja painetaan kudosta vasten, vaikuttavat sähkölopetuksen voimakkuuteen. On havaittu, että virta kulkee ketun läpi hyvin, jos yksi elektrodeista asetetaan oikein ketun peräaukkoon ja toinen ketun suuhun. Virta aiheuttaa epileptisen kohtauksen aivoissa ja kammiovärinän tai sydämen pysähdyksen. On varmistettava, että liikkumista rajoittavat laitteet tai muut materiaalit eivät vaikuta sähkövirran johtumisreittiin tai tehokkuuteen. Monet fysiologiset ominaisuudet, kuten esimerkiksi ruumiin koko, vaikuttavat myös virran kulkuun. Tämä vuoksi jännitteen ja virran tulisi olla riittävän korkeita läpäistäkseen myös kaikkein isoimpien kettujen kehon vastuksen.

\section{Sähköiskun estäminen ennen tainnutusta}

On varmistettava, että eläin ei saa sähköiskuja ennen varsinaista tainnutusta. Ennenaikaisia sähköiskuja voidaan estää käyttämällä oikeanlaista laitteistoa, joka on suunniteltu erityisesti lopetustarkoitukseen. Laitteistossa on oltava virtakytkin. Silloin virta ei kulje eläimen läpi ennen kuin lopetuksen suorittava henkilö painaa virtapainiketta, vaikka elektrodit olisikin asetettu paikoilleen jo aikaisemmin. Elektrodit on laitettava eläimelle vasta kun sen liikkuminen on rajoitettu. Lopetuksen suorittajan epävarma ja huolimaton toiminta saattaa aiheuttaa tahattomia sähköiskuja ennen varsinaista taintumista. Sen vuoksi on tärkeää, että lopetuksen suorittajalla on riittävä koulutus ja kokemus lopetuslaitteen käytöstä. Muut fysikaaliset sähkölopetukseen vaikuttavat tekijät, kuten sähköjohtojen kunto, on tarkistettava. Ympäristö, jossa lopetus suoritetaan, on pidettävä siistinä ja sieltä poistettava kaikki johtavat materiaalit, jotka voivat aiheuttaa tahattoman sähköiskun (esim. märkä lattia tai muut tasot, irtonaiset johtavat narut ja metallijohdot jne.). Ympäristö on oltava suojattu sateelta ja kosteudelta. 


\section{Elektrodien paikka ja kosketuspinta-ala}

Elektrodien sijainti vaikuttaa virran johtumisreittiin. Jotta virta aiheuttaisi tajuttomuuden, sydämen kammiovärinän ja sydänpysähdyksen, elektrodit on asetettava siten, että virta kulkee sekä aivojen että sydämen läpi. Kettujen päähän ja kehoon kohdistuvassa sähkölopetuksessa yksi elektrodi on asetettava tarpeeksi syvälle peräaukkoon ja toinen elektrodi ketun suuhun. Tällä tavalla asetettuna virta vaikuttaa sekä aivoihin että sydämeen. Puikkomaiset elektrodit johtavat virtaa hyvin, kun ne kohdistetaan oikein. Sähkön vaikutuksia sijoitettaessa elektrodit muihin ruumiinosiin kuin suuhun ja peräaukkoon ei ole tutkittu. Muihin ruumiinosiin kohdistettua sähkötainnutusta tai -lopetusta ei sen vuoksi suositella.

Jos päähän kohdistuvaa sähkötainnutusta käytetään, on elektrodit sijoitettava kallon molemmille puolille, jotta sähkövirta kulkee aivojen läpi. Elektrodit on painettava tiukasti kalloa vasten, kuitenkin eläintä satuttamatta.

\section{Kirjallisuus:}

Korhonen, H. T. \& Huuki, H. 2012. Hyvän toimintatavan opas minkin lopetukseen. MTT 7.5.2012. $37 \mathrm{~s}$.

Korhonen, H.T., Cizinauskas, S. \& Jesernics, J. 2012. Electrophysiological study on $\mathrm{CO}$ and $\mathrm{CO}_{2}$ euthanasia in mink (Mustela vison). Ann. Anim. Sci. 12(4): 597-608.

Korhonen, H.T. \& Huuki, H. 2013a. Neovison vison: Code of good practice for euthanasia in mink. Sosiohumanika 6(1):69-76.

Korhonen, H.T. \& Huuki, H. 2013b. Hyvä toimintatapa kettujen lopetuksessa. MTT 15.4.2013. $29 \mathrm{~s}$.

Korhonen, H.T., Eskeli, P., Sepponen, J. \& Toikkanen, P. 2013. Individual and group euthanasia in farmed mink. Ann. Anim. sci. 13(3): 623-632. 